\title{
Phytochemicals Analysis and Minerals Present in the dried used as spices: Health Risk Implication in Northern of Iraq
}

\author{
RAMAL AHMED MUSTAFA \\ Chemistry department, College of Education, University of Garmian-kalar city -Iraq 46021 \\ Correspondence to Ramal Ahmed Mustafa, Email: ramal.ahmed@garmian.edu.krd
}

\begin{abstract}
In this study, total concentrations of eleven chemical elements ( $\mathrm{Ba}, \mathrm{Ca}, \mathrm{Cu}, \mathrm{Fe}, \mathrm{K}, \mathrm{Na}, \mathrm{Mn}, \mathrm{Ni}, \mathrm{Zn}, \mathrm{P}$ and $\mathrm{Mg}$ ) in common spices of Kalar city- Iraq were determined using inductively coupled plasma-optical emission spectrometry. This study indicates that spices are a good source of a combination of $\mathrm{Ca}, \mathrm{K}, \mathrm{Na}, \mathrm{P}$ and $\mathrm{Mg}$. The spices, Curcuma longa, Nigella Sativa and Elettaria cardamomum were found to be very good sources of essential trace elements like Fe, $\mathrm{Zn}$ and $\mathrm{Mn}$. The concentrations of the all elements were within the WHO and FAO permissible levels. Therefore, health risks associated with these elements indicate that people would experience no potential risks due to consumption of the spices. Preliminary screening of phytochemicals has found plenty of secondary metabolites which are present in dry plant samples. EDI values of all the metals were found to be below the maximum tolerable daily intake (MTDI). The present review aims to provide a comprehensive summary of the most relevant and recent findings on spices and their active compounds in terms of targets and mode of action; in particular, their potential use in food preservation and enhancement of shelf life as a natural bio ingredient.
\end{abstract}

Keywords: Spices, phytochemicals, food preservative, Minerals, Ash digestion, inductively coupled plasma - optical emission spectrometry, ICP-OES.

\section{INTRODUCTION}

Spices refer to all nutritious parts of a plant that are used for aroma, preservative, color, acceptability, and deliciousness of cooking food, Spice dependency is reported in more than $70 \%$ of the world population ${ }^{1}$. The use of this spices have a substantial dietary and medicinal importance, although they have diversity in composition ${ }^{2}$. Medicinal applications may be due to the presence of organic bioactive compounds, vitamins and minerals.Nutritional value of minerals among these ingredients are significant.

Minerals can be classified into macro (sodium (Na), potassium $(\mathrm{K})$, calcium $(\mathrm{Ca})$ and magnesium $(\mathrm{Mg})$ ) and micro (chromium $(\mathrm{Cr})$, copper $(\mathrm{Cu})$, iron (Fe), manganese $(\mathrm{Mn})$, and zinc $(\mathrm{Zn})$ ) minerals based on their natural occurrence. Minerals contribute meaningfully to the numerous metabolic roles in living cells ${ }^{3}$. Accumulation of mineral elements in plants and herbs can assist in several functions of the body growth. Iron function is critical in oxygen transport, oxidative metabolism and cellular growth. Similarly, $\mathrm{Cu}$ and $\mathrm{Ca}$ also plays an important role in several physiological action ${ }^{1}$. $\mathrm{Zn}$ is particularly essential for cell immune response and replication. Minerals have beneficial effects but can toxicity following excess consumption ${ }^{4}$. Nevertheless, the minerals may possibly be added to the diet by the consumption of spices and herbs ${ }^{5}$. The occurrence of elevated levels of minerals in spices and medicinal plants varied depending on the plant origin, the environmental impacts, part used of plants and technological processes ${ }^{6}$. According the previous studied macro and micro mineral composition of Pakistani common spices. Results showed that the contents of $\mathrm{Na}, \mathrm{K}, \mathrm{Ca}$ and $\mathrm{Mg}$ were significantly higher in all the spices $(p<0.05)^{7}$. Contamination with heavy metals is important, particularly in agricultural production systems and human health. Factors influencing the concentration of heavy metals in plants include climate, environmental pollution, nature of the soil on which the plant is grown, and the degree of maturity of the plant at the time of harvesting 8 .

Previously published methods were either costly or did not allow simultaneous determination of the concerned micro minerals. Inductively coupled plasma with optical emission spectrometry (ICP-OES) is a well-established approach for multi elemental techniques and determination of isotope ratios. This method allows simultaneous Trace elements identification and quantification in the sample and has been successfully implemented in this study.

To our knowledge, there were no research articles on the elemental content of dried plants as spices in Iraq. Therefore, the objective of this study is to determine the levels of elements such as $\mathrm{Ba}, \mathrm{Ca}, \mathrm{Cu}, \mathrm{Fe}, \mathrm{K}, \mathrm{Na}, \mathrm{Mn}, \mathrm{Ni}$, $\mathrm{Zn}, \mathrm{P}$ and $\mathrm{Mg}$ in ten common spices, as well as evaluate the phytochemical quantities analysis of the common spices.

That are widely and habitually consumed in Kalar city as a Slemani area-Iraq. The ash residue digestion and ICP-OES techniques are validate for these analyses.

\section{MATERIALS AND METHODS}

Selection of Sample: A total of 60 of samples of 10 common spices were collected from the local markets in the Kalar city - Iraq country. Currently, the common spices were selected such as:Capsicum annuum $(n=6)$, Capsicum carvi $(\mathrm{n}=6)$, Zingiber officinale $(\mathrm{n}=6)$, Elettaria cardamomum $(n=6)$, Piper nigrum $(n=6)$, Nigella Sativa $(n=6)$, Cinnamomum verum $(n=6)$. The common scientific and family names of plants species are indicated in (Table 1). Each spice sample was cleaned of debris, sorted, graded, trimmed and ground to a fine powder using a culatti grinder (Polymix, France) fitted with a $500 \mu \mathrm{m}$ mesh [9]. Each ground sample was then sealed in polyethylene plastic and stored at $4^{\circ} \mathrm{C}$ in a refrigerator until needed for analysis.

ICP-OES analysis: In order to estimate the content of the concentrations of macro- and micro elements, the 
calibration standards were prepared. Multistandard IV standard solution (Merck), which contained $\mathrm{Ba}, \mathrm{Ca}, \mathrm{Cu}, \mathrm{Fe}$, $\mathrm{K}, \mathrm{Na}, \mathrm{Mn}, \mathrm{Ni}, \mathrm{Zn}, \mathrm{P}$ and $\mathrm{Mg}$ at the concentration of 1000 $\mathrm{mg} / \mathrm{kg}$ was used for the preparation of calibration solutions. Distilled water, purified by Fisher Chemical (HPLC grade) was used for the dilution of the standard solution, as well as for the dilution of spices samples. The preparation of standard solutions was performed by diluting the standard, so that the concentrations of standards for the calibration charts were in the range of expected test elements concentrations. The carrier gas was Argon 5.0 (99.999\% purity). Table 2 shows the wavelengths, Measurement Parameters and Standards for each Element.

Estimated daily intake of heavy metals: Estimated daily intakes (EDIs) of heavy metals were calculated using their respective average concentration in food samples by the weight of food items consumed by an individual (body weight $65 \mathrm{~kg}$ for an adult in Iraq )[10] (FAO, 2006), which was obtained from the household income and expenditure survey ${ }^{11}$ and calculated by the following formula:

EDI: ( FIR ${ }^{*} \mathbf{c}$ )/ BW: Where FIR is the food ingestion rate ( $\mathrm{g} /$ person/day), $\mathbf{C}$ is the metal concentration in food samples $(\mathrm{mg} / \mathrm{kg})$, and BW is the body weight.

Qualitative analysis of phytochemicals: Qualitative analysis was carried out to ascertain the presence of the different phytochemicals (Steroid and Alkaloids) in the spiced samples using standard procedure ${ }^{12}$.

Test for flavonoids: Few drops of $1 \% \mathrm{NH} 3$ solution was added to the aqueous solution of spices sample in a test tube. A yellow coloration was observed which indicated the presence of flavonoid compounds.

Test for tannins: $\mathrm{FeCl} 3(0.1 \%)$ was added to $5 \mathrm{ml}$ of the samples and observed for brownish green or a blue black colorations, which shows the presence of tannins ${ }^{13}$.

\section{RESULTS AND DISCUSSION}

The concentration of $\mathrm{Ba}, \mathrm{Ca}, \mathrm{Cu}, \mathrm{Fe}, \mathrm{K}, \mathrm{Na}, \mathrm{Mn}, \mathrm{Ni}, \mathrm{Zn}, \mathrm{P}$ and $\mathrm{Mg}$ were analyzed in 10 common spices listed in Table 3. Mean $k$ content was highest in all samples. The high levels of $\mathrm{k}$ were observed in the Zingiber officinale (9242.65 $\mathrm{mg} / \mathrm{kg}$ ), while the lowest concentration for Laurus nobilis (3082.6 $\mathrm{mg} / \mathrm{kg}$ ) (Table 3 and Figure 1 ). $\mathrm{K}$ is the most abundant intracellular into create a distribution of electrical potentials in nervous tissues. However, a lower level of $\mathrm{K}$ cause of human severe neurological dysfunctions ${ }^{14}$.

The concentrations of $\mathrm{Ca}$ in Laurus nobilis was significantly higher as compared to rest of the studied common spices $(p>0.05)$. Thelowest was observed in Piper guineense $(61.45 \mathrm{mg} / \mathrm{kg})$. High concentrations of $\mathrm{Ca}(>40000 \mathrm{mg} / \mathrm{kg})$ can significantly improve strengthen the bones, muscles, teeth and function of heart.All spices studied exhibited satisfactory contents of the $\mathrm{Ca}$ (Table 3 ). The $\mathrm{Ca}$ content in decreasing order was Laurus nobilis $>$ Cinnamomum verum $>$ Nigella Sativa $>$ Capsicum annuum $>$ Capsicum carvi $>$ Elettaria cardamomum $>$

Piper nigrum>Zingiber officinale>Piper guineense. Capsicum carvi

The lowest amount of all mineral was Ni.The concentration of $\mathrm{Ni}$ was found in the range of $0.075-1.425 \mathrm{mg} / \mathrm{kg}$ in all the studied spices. The highest contents of $\mathrm{Ni}$ were obtained in the Nigella Sativa $(1.425 \mathrm{mg} / \mathrm{kg})$ and lowest was found in the Cinnamomum verum $(0.075 \mathrm{mg} / \mathrm{kg}$ )
(Table 3).According to Codex, the maximum intake of $\mathrm{Ni}$ for fruit samples was $0.8 \mathrm{mg} / \mathrm{kg}$. Ni is also a micronutritient essential for proper functioning of the human body, as it increases hormonal activity and is involved in lipid metabolism [15].Piper guineense is a major source of $\mathrm{Na}$ $(3026.3 \mathrm{mg} / \mathrm{kg}) . \mathrm{In}$ the body, $\mathrm{Na}$ is the most common action that contributes in the water metabolism, the contraction of muscles and allows the transfer of carbon - dioxide to the lungs.Mg plays an important role in human health, acts as a regulating blood calcium concentrations and vasodilation [16]. The highest content of $\mathrm{Mg}(611.375 \mathrm{mg} / \mathrm{kg})$ was observed in the Piper nigrum, although the lowest concentration observed in the Laurus nobilis (398.3 mg/kg) (Table 3).

The contents of Fe were found too low in all studied spices than the WHO maximum permissible limit for $\mathrm{Fe}$ in the medicinal plants $(300 \mathrm{mg} / \mathrm{kg})[17]$.The current study therefore provides public awareness based on concentration of essential nutrient in the spices [18]. Fe is important not only for Human growth and blood production but also important for metabolic processes, including oxygen transport, DNA synthesis, and electron transport [19].

In the studied spices results showed that the contents of $\mathrm{Mn}$ were within the WHO maximum permissible limit for $\mathrm{Mn}$ in the medicinal plants $(100 \mathrm{mg} / \mathrm{kg})$. The highest and lowest concentrations of Mn were found in Elettaria cardamomum (39.3 $\mathrm{mg} / \mathrm{kg}$ ) and Curcuma longa (10.575 mg/kg), respectively (Table 3 ). $\mathrm{Zn}$ is a chemical element required for growth, development, muscle and nerve function[20].The lowest and highest $\mathrm{Zn}$ concentration in spices was detected in Capsicum annuum $6.27 \mathrm{mg} / \mathrm{kg}$ and Nigella Sativa $15.3 \mathrm{mg} / \mathrm{kg}$, respectively (Table 1). From the present study, mean $\mathrm{Zn}$ concentration in spices followed the descending order of:Nigella Sativa $>$ Laurus nobilis $>$ Zingiber officinale $>$ Piper nigrum $>$ Elettaria cardamomum $>$ Piper guineense $>$ Capsicum annuum $=$ Curcuma longa $>$ Cinnamomum verum $>$ Capsicum annuum.As set by WHO/FAO, the recommended limit for $\mathrm{Zn}$ is $100 \mathrm{mg} / \mathrm{kg}$ [21].

$\mathrm{Cu}$ is a key component of many enzymes, therefore can be performed pivotal role in different physiological processes like antioxidant defense, free radicals elimination, respiration, melanin production, and many others. In the present study, the mean highest concentration of $\mathrm{Cu}$ was found in Piper guineense $(2.15 \mathrm{mg} / \mathrm{kg}$ ) and lowest in Cinnamomum verum $(0.8 \mathrm{mg} / \mathrm{kg})$ as shown in Table 3 . These

values are within maximum permissible limit prescribed by WHO (50 $\mathrm{mg} / \mathrm{kg}$ ). Hence, excessive consumption of $\mathrm{Cu}$ by foodstuff can result in irritation of the upper respiratory tract, dermatitis, abdominal pain, nausea, diarrhoea, vomiting, and liver damage [22].

Heavy non-essential metals such as $\mathrm{Ba}$ was determined in the spices at trace levels. Ba is present in all spices in minor concentration except in Cinnamomum verum. The concentration of $\mathrm{Ba}$ varies between $0.025 \mathrm{mg} / \mathrm{kg}$ in Piper guineense to $50.25 \mathrm{mg} / \mathrm{kg}$ in Cinnamomum verum.Ba exposure for human may occur through oral, dermal and inhalation routes, non-occupational exposure in the general population is mainly through oral route by consumption of food and water[23]. The impacts of $\mathrm{Ba}$ 
exposure on humans is associated with adverse consequences including pulmonary edema, cardiac and/or renal failure, respiratory paralysis and gastric and respiratory hemorrhages [24].

The phytochemical constituents of the spiced fruit drink are shown in Table 4 . The result of ten aqueous extract the spices qualitative analysis on each spiced showed the presence of phytochemical constituents such as alkaloids, flavonoids, tannins and steroids. According the results tannins and flavonoids while tannin was slightly present in Cinnamomum verum, Curcuma longa and Piper guineense. Alkaloids has been found to have antimicrobial activity and the major anti-diarrheal effect is probably due to their effects on small intestine and antihypertensive antifungal, antiinflammatory, antifibrogenic effect [25]. While tannin is a non-toxic and can they generate physiological responses in animals that consume them. The presence of tannin in the medicinal plant suggests the ability of these plants to play key roles as antifungal antidiarrheal, antioxidant and antihemorrhoidal agent [2].

In this study, aqueous extract the spices of $C$. annuum, $C$. carvi and N. Sativa contained flavonoid. It modifies the body's reaction to allergens, virus and caranogens. It has been reported to show anti-inflammatory, antifungal, antibacterial and antimicrobial activities based on the literature [26].

Steroids showed the analgesic properties, Panche, et., al., (2016) reported the role of steroid as anti-inflammatory and analgesic agents. Steroid and Saponin are responsible for central nervous system activities. According the (table 4), most of the samples in this study are containing the Steroid, that can be used as a main food in our diet.

The estimation daily intake of five metals ( $\mathrm{Fe}, \mathrm{Mn}, \mathrm{Zn}, \mathrm{Ba}$ and $\mathrm{Ni}$ ) was calculated according to the mean concentration of each metal in each spices and the respective consumption rates. The EDI and maximum tolerable daily intake (MTDI) of studied metals from consumption of fruits and vegetables are shown in (table $5)$.

The average per capita daily intake of spices in Iraq is between $5 \mathrm{~g}$ to $20 \mathrm{~g}$, they used for a different purpose according of type of spices, the results show in (table 5), in this study calculated (5 and $7.5 \mathrm{~g} /$ person /day) if the consumer $65 \mathrm{~kg}$ [27].

In Curcuma longa sample recorded Fe (3.431 mg/kg) higher ratio in daily intake, while $\mathrm{Ni}$ and $\mathrm{Ba}$ was lowest ration recorded, in other hand $\mathrm{Zn}$ in Zingiber officinale were ( higher ration among the minerals Daily intakes of all the metals were less than the MTDI. Different types of spices are grown throughout the year, but there is a lack of information on their metal contents [28].

However, few previous studies on heavy metal contents in fruits and vegetables were conducted sporadically, but they were confined to a specific region [29].

Heavy metals in higher concentration ranges have been reported in vegetables grown with wastewaters compared to those grown with groundwater. Furthermore, higher concentrations of these metals have been found in leafy vegetables compared to those in other types of vegetables such as bulbs and tubers.
Heavy metals may enter the body of an organism directly from the abiotic environment, i.e., water, sediments, and soil or may enter the organism body from its food/prey [29]. Spices have yielded a slew of natural substances with welldefined antibacterial activities. In vitro investigations, on the other hand, only represent a small portion of the total number of active chemicals. The use of preservatives in food Furthermore, their physical and biological properties Real-life food systems have had their qualities altered as a result of the matrix of food's complexity [30]. As a result, whether spices or their components have the ability to cause cancer is debatable to function as food preservation and inhibit food spoilage been determined in different studies.

Spices as preservatives have been evaluated in a variety of foods, including meat, fish, dairy products, vegetables, rice, fruit, and animal feeds, as detailed in (Table 6).

The antibacterial activity of several spice extracts in raw chicken flesh was also investigated after 15 days of storage at $4^{\circ} \mathrm{C}$. The use of extracts of clove, oregano, cinnamon, and black mustard on raw chicken meat was found to be efficient in inhibiting microbial development [11] .

The use of combination extracts or natural compounds of different origins has been documented to improve the antibacterial properties of spices or their constituents [31] The use of spice oil in conjunction with other preservation methods has also been evaluated. Low-pressure environments, for example, increased E.coli and S.enteritidis susceptibility. Essential oils like oregano, lemongrass, or cinnamon in vitro The MIC of cinnamon vapors for S.enteritidis in specific reduced from 0.512 to $0.128 \mathrm{~L} / \mathrm{mL}$, due to the synergistic activities of antimicrobial components found in the combined spices, the mixture of the three extracts had the greatest influence on the bacterial burden [32]. Phenylpropenes, such as eugenol and cinnamaldehyde [33], are other chemical substances found in spices. Eugenol's antibacterial activity is mostly at the cellular level[33] . permeabilization and permeabilization of membranes and proteins the enzyme in the process of activation[34] . Some other studied antioxidants are: capsaicin (red chilli), curcumin (turmeric), Gingerol, Shogoal (ingiber officinale), Terpinylacetate (Elettaria cardamomum), piperine (black pepper), gingerol, etc [35].

\section{CONCLUSION}

Many elements have been suggested as essential, but such claims have usually not been confirmed. Recent studies have shown a tight linkage between living organisms and minerals on this planet. Mineral nutrients are referred to the smaller class of minerals that are metabolized for growth, development and vitality of living organisms. Studied were found in this order the level were higher values in black seed and laurus leaves were higher values in calcium content. The levels of copper were relatively low in all spices In general, the concentrations of macronutrients confirmed a positive nutritional Contribution. These discoveries may serve as the foundation for further research to identify other active compounds that may have health benefits and, as a result, may lead to new drugs. 
Considering phytochemicals are not considered nutrients, there are no formal guidelines for how much of each active element should be ingested to achieve the best results. As a result, efforts should be made to ascertain the quantitative requirements of these active phytochemical elements for intake.

(Table 1): Name and parts of the spices used in the study.

\begin{tabular}{|l|l|l|l|}
\hline Elements & Wave length $(\mathrm{nm})$ & Plasma (L/min) & View mode \\
\hline Barium $(\mathrm{Ba})$ & 206.200 & 16 & Axial \\
\hline Calcium $(\mathrm{Ca})$ & 393.366 & 16 & Axial \\
\hline Copper $(\mathrm{Cu})$ & 227.393 & 16 & Axial \\
\hline Iron $(\mathrm{Fe})$ & 238.204 & 16 & Radial \\
\hline Potassium $(\mathrm{K})$ & 766.490 & 16 & Radial \\
\hline Manganese $(\mathrm{Mn})$ & 257.610 & 16 & Radial \\
\hline Sodium $(\mathrm{Na})$ & 589.592 & 16 & Radial \\
\hline Nickel Ni & 590.000 & 16 & Axial \\
\hline Phosphorous $(\mathrm{P})$ & 213.617 & 16 & Radial \\
\hline Magnesium $\mathrm{Mg}$ & 280.271 & 16 & Axial \\
\hline
\end{tabular}

Table 2: Wavelengths, Measurement Parameters and Standards for each Element

\begin{tabular}{|l|l|l|l|l|}
\hline $\begin{array}{l}\text { Samples Code } \\
\text { (DW) }\end{array}$ & Vernacular name & Botanical name & Common function & plant part \\
\hline D1 & Red chill & Capsicum annuum & Meat Spices & Fruit \\
\hline D2 & Red chill & Capsicum carvi & Sweet red pepper & Fruit \\
\hline D3 & Ginger root & Zingiber officinale & Ginger root & root \\
\hline D4 & Green Cardamom & Elettaria cardamomum & Cardamom & seeds \\
\hline D5 & Black pepper & Piper nigrum & Black pepper & Fruit \\
\hline D6 & & Piper guineense & Fruit \\
\hline D7 & Nigella seed & Nigella Sativa & Black seed & Seed \\
\hline D8 & Cinnamon & Cinnamomum verum & Cinnamon & bark \\
\hline D9 & & Curcuma longa & Turmeric & rhizome \\
\hline D10 & Bay leaf & Laurus nobilis & Laurel leaves & leaf \\
\hline
\end{tabular}

Table 3. Spices minerals content $(\mathrm{mg} / \mathrm{kg})$ obtained by ICP-OES method.

\begin{tabular}{|c|c|c|c|c|c|c|c|c|c|c|c|}
\hline $\begin{array}{c}\text { Sample } \\
\text { /minerals }\end{array}$ & $\mathrm{Ba}$ & $\mathrm{Ca}$ & $\mathrm{Cu}$ & $\mathrm{Fe}$ & $\mathrm{K}$ & $\mathrm{Mn}$ & $\mathrm{Na}$ & $\mathrm{Ni}$ & $\mathrm{P}$ & $\mathrm{Zn}$ & $\mathrm{Mg}$ \\
\hline D1 & 5.325 & 606.85 & 1.52 & 28.15 & 8390.1 & 25.1 & 2910.4 & 0.3 & 1309.125 & 6.275 & 486.35 \\
\hline D2 & 3.175 & 512.95 & 1.6 & 15.5 & 6674.525 & 13.1 & 174.8 & 0.125 & 689.075 & 8.9 & 430.1 \\
\hline D3 & 14.875 & 228.325 & 2.05 & 24.2 & 9242.65 & 33.9 & 584.25 & 0.75 & 1058.05 & 12.375 & 526.45 \\
\hline D4 & 26.475 & 479.1 & 2.075 & 14.5 & 4402.3 & 39.3 & 1826.6 & 0.125 & 838.075 & 10.9 & 503.05 \\
\hline D5 & 8.425 & 243.3 & 1.7 & 17.87 & 7315.55 & 21.175 & 1159.9 & 0.4 & 1869.425 & 12.15 & 611.375 \\
\hline D6 & 0.025 & 61.45 & 2.15 & 18.82 & 4431.375 & 12.9 & 3026.3 & 0.65 & 948.475 & 9.1 & 429.01 \\
\hline D7 & 6.525 & 714.15 & 1.15 & 13.77 & 4400.65 & 13.9 & 1200 & 1.425 & 1550.4 & 15.3 & 593.475 \\
\hline D8 & 50.25 & 1003.8 & 0.8 & 12.4 & 3900.7 & 29.1 & 78.575 & 0.075 & 625.4 & 7.8 & 490.1 \\
\hline D9 & 5.9 & 106.575 & 0.925 & 29.1 & 4100.9 & 10.575 & 73.55 & 0.1 & 1420.675 & 8.9 & 578.275 \\
\hline D10 & 4.45 & 2098.32 & 1.525 & 17.47 & 3082.6 & 13.1 & 164.275 & 0.125 & 673.45 & 13.025 & 398.3 \\
\hline
\end{tabular}


Table 4.Qualitative analysis of the phytochemicals of Aqueous extract the Spices samples.

\begin{tabular}{|c|c|c|c|c|}
\hline Samples Code (DW) & Alkaloids & Flavonoids & Tannins & Steroids \\
\hline D1 & ++ & ++ & ++ & ++ \\
\hline D2 & ++ & ++ & ++ & ++ \\
\hline D3 & + & ++ & ++ & + \\
\hline D4 & -- & + & + & + \\
\hline D5 & + & ++ & + & + \\
\hline D6 & + & ++ & - & + \\
\hline D8 & + & ++ & + & + \\
\hline D9 & + & ++ & + & ++ \\
\hline D10 & - & ++ & + & + \\
\hline
\end{tabular}

+indicates presence,-indicates absence

Table 5. Comparison of the estimated daily intake (EDI) of trace metal (ppm) (5 and $7.5 \mathrm{~g} /$ day/person (65kg)) of Spices samples with the corresponding Maximum allowable concentration (MAC) in the Iraq population.

\begin{tabular}{|l|l|l|l|l|l|l|}
\hline \multirow{2}{*}{ Samples Code (DW) } & Consumption rate (g/day/person) & Fe & $\mathrm{Mn}$ & $\mathrm{Zn}$ & $\mathrm{Ba}$ & $\mathrm{Ni}$ \\
\hline \multirow{2}{*}{ D1 } & 5 & 2.165 & 1.931 & 0.483 & 0.429 & 0.024 \\
\cline { 2 - 6 } & 7.5 & 3.248 & 2.896 & 0.724 & 0.590 & 0.033 \\
\hline \multirow{2}{*}{ D3 } & 5 & 1.192 & 1.008 & 0.685 & 0.244 & 0.010 \\
\cline { 2 - 6 } & 7.5 & 1.788 & 1.512 & 1.027 & 0.366 & 0.014 \\
\hline \multirow{2}{*}{ D4 } & 5 & 1.862 & 2.608 & 20.625 & 1.144 & 0.058 \\
\cline { 2 - 6 } & 7.5 & 2.792 & 3.912 & 30.938 & 1.716 & 0.087 \\
\hline \multirow{2}{*}{ D5 } & 5 & 1.115 & 3.023 & 0.838 & 2.037 & 0.010 \\
\cline { 2 - 6 } & 7.5 & 1.673 & 4.535 & 1.258 & 3.055 & 0.014 \\
\hline \multirow{2}{*}{ D6 } & 5 & 1.375 & 1.629 & 0.935 & 0.648 & 0.031 \\
\hline \multirow{2}{*}{ D7 } & 5 & 2.062 & 2.443 & 1.402 & 0.972 & 0.046 \\
\cline { 2 - 6 } & 7.5 & 1.448 & 0.992 & 0.700 & 0.002 & 0.05 \\
\hline \multirow{2}{*}{ D8 } & 5 & 2.172 & 1.488 & 1.050 & 0.003 & 0.075 \\
\cline { 2 - 6 } & 7.5 & 1.059 & 1.069 & 1.177 & 0.502 & 0.110 \\
\hline \multirow{2}{*}{ D9 } & 5 & 1.589 & 1.604 & 1.765 & 0.753 & 0.164 \\
\cline { 2 - 6 } & 7.5 & 0.954 & 2.238 & 0.600 & 3.865 & 0.006 \\
\hline \multirow{2}{*}{ D10 } & 5 & 1.431 & 3.358 & 0.900 & 5.798 & 0.009 \\
\cline { 2 - 6 } & 7.5 & 2.238 & 0.813 & 0.685 & 0.454 & 0.008 \\
\hline MAC(FAO/WHO,2011) 2011 & 5 & 3.431 & 4.881 & 4.108 & 2.723 & 0.046 \\
\cline { 2 - 6 } & 7.5 & 1.344 & 1.008 & 1.002 & 0.342 & 0.010 \\
\hline
\end{tabular}

\begin{tabular}{|c|c|c|c|}
\hline Scientific name & Real food models. Anti- Microorganisms activity & Major compounds & References \\
\hline $\begin{array}{l}\text { Capsicum } \\
\text { annuum }\end{array}$ & $\begin{array}{l}\text { Inhibitthegrowth B.cereus,S. Typhimuriumand St.aureus/ antibacterialagents, } \\
\text { Inrefrigeratedchickencontrol Ls.monocytogenes inbovinegroundmeatSt. aureus, S. Typhimurium }\end{array}$ & Capsaicin & [36] \\
\hline Capsicum carvi & $\begin{array}{l}\text { Raw chicken meat in Fresh sliced apples reduces natural microflora andinoculated Ls.innocua } \\
\text { St. aureus, S. Typhimurium }\end{array}$ & $\begin{array}{l}\text { Limonene, carvone, } \\
\text { carvacron, anethole }\end{array}$ & [37] \\
\hline $\begin{array}{l}\text { Zingiber } \\
\text { officinale }\end{array}$ & $\begin{array}{l}\text { Potential bio-preservative of beverages against food spoiling yeasts and bacteria } \\
\text { (E.coli,Salmonella spp.,Streptococci) }\end{array}$ & Gingerol, Shogoal & [38] \\
\hline $\begin{array}{l}\text { Elettaria } \\
\text { cardamomum }\end{array}$ & ReducethegrowthofLs.monocytogenes inpineapplejuice (B. cereus, Ls. Monocytogen) & $\begin{array}{l}\text {,8-Cineole, Linalool, - } \\
\text { Terpinylacetate }\end{array}$ & [39] \\
\hline Piper nigrum & $\begin{array}{l}\text { Oil and oleoresins control microbial growth in orange juice(St. aureus, E. coli, . cereus, } P \text {. } \\
\text { aeruginosa }\end{array}$ & Piperine & [40] \\
\hline Piper guineense & St. aureus, E. coli Flavonoids, Polyphenols B. cereus, P. aeruginosa & $\begin{array}{l}\text { Lignans, Amides, } \\
\text { Alkaloids, }\end{array}$ & [41] \\
\hline Nigella Sativa & Were more effective on St. aureus (5th day inhibition zone $34 \mathrm{~mm}$ ) and E. coli. & $\begin{array}{l}\text { Thymoquinone, } \\
\text { Nigellone }\end{array}$ & [34] \\
\hline $\begin{array}{l}\text { Cinnamomum } \\
\text { verum }\end{array}$ & $\begin{array}{l}\text { Potential bio preservative of banana, vegetables, dairy products, against Aspergillus spp., } \\
\text { Salmonella spp. }\end{array}$ & $\begin{array}{l}\text { Cinnamic aldehyde, } \\
\text { eugeno }\end{array}$ & [42] \\
\hline Curcuma longa & $\begin{array}{l}\text { Cumin seed oil protect stored protection of wheat andchickpeaagainst Aspergillus spp. } \\
\text { Reducetotalbacteriainmeatsamples (S. Typhi, Ls. Monocytogenes, St. aureus, E. coli, B. cereus, } \\
\text { B. subtilis, C. albicans, Y. enterocolitica, P. notatum, S. cerevisiae) }\end{array}$ & Curcumin & [43] \\
\hline Laurus nobilis & $\begin{array}{l}\text { Bay essential oil reduce the population of total coliforms in fresh sausages Protects cherry } \\
\text { tomatoes against Alternation alternate infectionand } E \text {. coli. }\end{array}$ & $\begin{array}{l}1,8 \text {-cineole, } \alpha- \\
\text { pipene, limonene }\end{array}$ & [44] \\
\hline
\end{tabular}




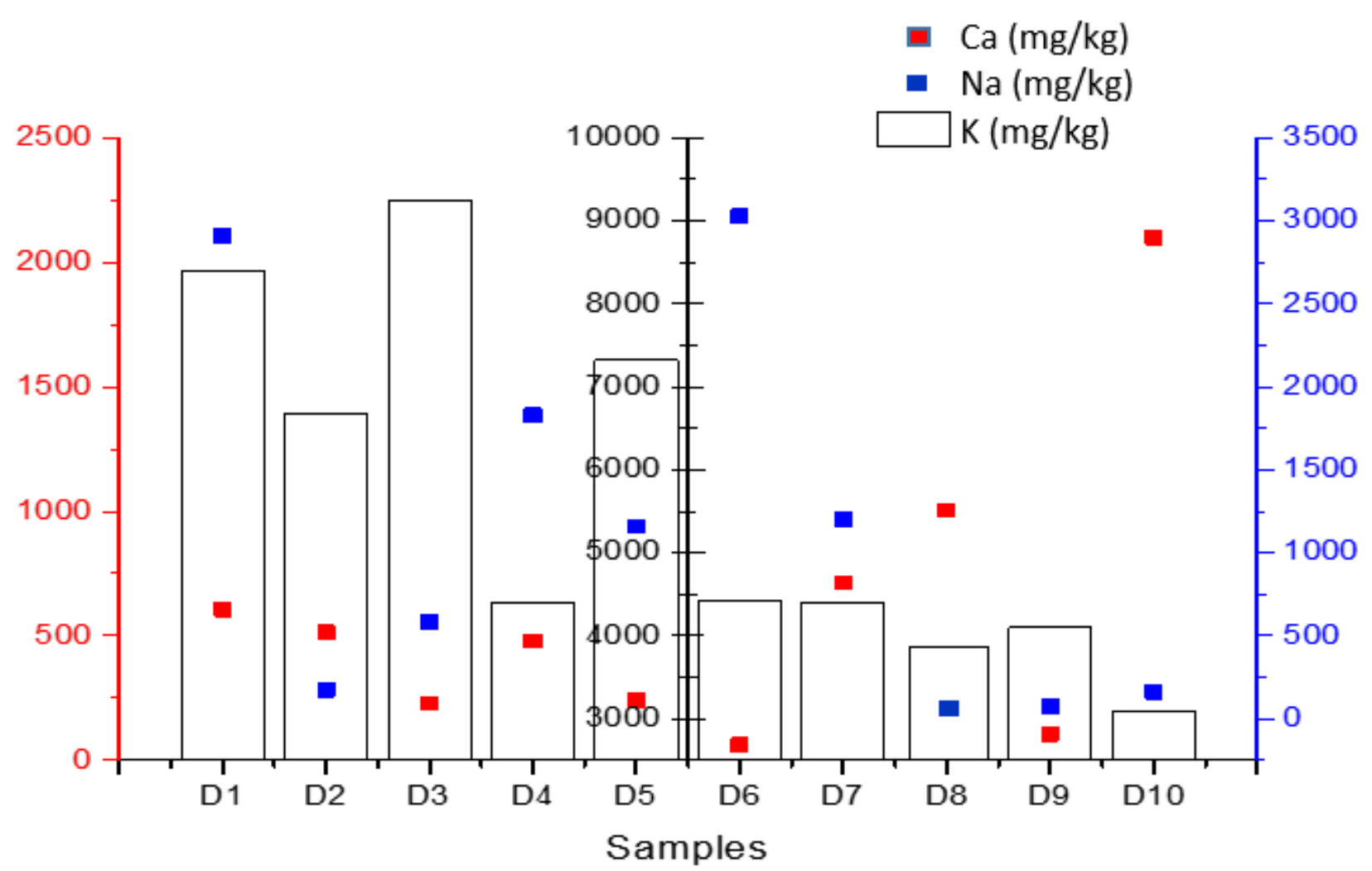

Figure 1. $\mathrm{Ca}, \mathrm{K}$ and $\mathrm{Na}(\mathrm{mg} / \mathrm{kg})$ content in selected spices plants
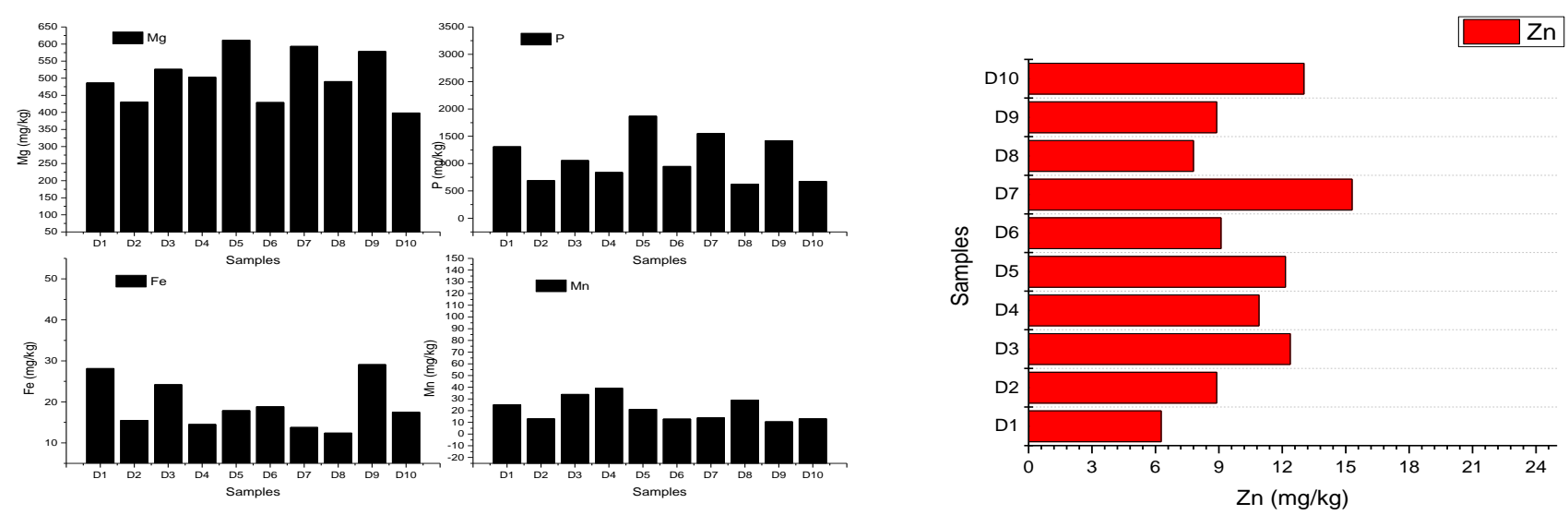

Figure 2. $\mathrm{Mg}$, Fe and $\mathrm{Mn}(\mathrm{mg} / \mathrm{kg})$ content in selected spices plants.

\section{REFERENCES}

1. A. Dehelean and D. A. Magdas, "Analysis of mineral and heavy metal content of some commercial fruit juices by inductively coupled plasma mass spectrometry," Sci. World J., vol. 2013, no. December, 2013, doi: $10.1155 / 2013 / 215423$.
Figure 3. Zn (mg/kg) content in selected spices plants.

2. I. O. Acham, M. O. Eke, and J. Edah, "Physicochemical, microbiological and sensory quality of juice mix produced from watermelon fruit pulp and baobab fruit pulp powder," Croat. J. food Sci. Technol., vol. 12, no. 1, pp. 48-55, 2020, doi: $10.17508 /$ cjfst.2020.12.1.07.

3. A. A. Bouba, N. Y. Njintang, H. S. Foyet, J. Scher, D. Montet, and C. M. F. Mbofung, "Proximate Composition, Mineral and Vitamin Content of Some Wild Plants Used as 
Spices in Cameroon," Food Nutr. Sci., vol. 03, no. 04, pp. 423-432, 2012, doi: 10.4236/fns.2012.34061.

4. A. M. A. Al-Lami, S. R. Khudhaier, and O. A. Aswad, "Effects of heavy metals pollution on human health," Ann. Trop. Med. Public Heal., vol. 23, no. 11, 2020, doi: 10.36295/asro.2020.231125.

5. J. Bitting and P. W. Sherman, "Antimicrobial Functions of Spices-Why Some Like It Hot," Q. Rev. Biol., vol. 73, no. 1, pp. 3-49, 1998.

6. A. Bukunmi Aborisade, "Phytochemical and Proximate Analysis of Some Medicinal Leaves," Clin. Med. Res., vol. 6, no. 6, p. 209, 2017, doi: 10.11648/j.cmr.20170606.16.

7. S. R. Pastor J., García M., Steinbauer S., Setzer W. N. and G. L. and M. L., "Combinations of ascaridole, carvacrol, and caryophyllene oxide against Leishmania," Acta Trop. J., vol. 135, pp. 31-38, 2015.

8. Islam, M.S., Ahmed, M.K., Habibullah-Al-Mamun, M., "Determination of heavy metals in fish and vegetables in Bangladesh and health implications. Hum. Ecol. Risk. Assess. 21 (4), 986e1006. Jarup, L., 2003. Hazards of heavy metals," Hum. Ecol. Risk. Assess, vol. 21, no. 4, pp. 9861003, 2015.

9. AOAC, Association of Official Analytical Chemists. Washington DC, 1990.

10. A. Heikens, "Arsenic contamination of irrigation water, soil and crops in Bangladesh: Risk implications for sustainable agriculture and food safety in Asia," FAO - RAP Publ. 2006/20, vol. 20, p. 2, 2006.

11. S. Khalid et al., "A review of environmental contamination and health risk assessment of wastewater use for crop irrigation with a focus on low and high-income countries," Int. J. Environ. Res. Public Health, vol. 15, no. 5, pp. 1-36, 2018, doi: 10.3390/ijerph15050895.

12. J. C. Usman, H. and Osuji, "Phytochemical and in vitro antimicrobial assay of the leaf extract of Newbouldia leavis.," Afr. J. Trad., vol. 4, no. 4, pp. 476-480, 2007.

13. N. and V. D. Lata, "Quantification and identification of alkaloids of Eichhornia crassipes: the world's worst aquatic plant," J. Pharm. Res., vol. 3, no. 6, pp. 1229 - 1231, 2010.

14. R.

Patrignani,F.,Siroli,L.,Serrazanetti,D.I.,Gardini,F.,andLanciott i,

"Innovativestrategiesbasedontheuseofessentialoilsandtheirc omponents toimprovesafety,shelflifeandqualityofminimallyprocessedfruitsand vegetables.," TrendsFoodSci.Tech, vol. 46, pp. 311-319, 2015.

15. S.

harafi,S.M.,Rasooli,I.,Owlia,P.,Taghizadeh,M.,andAstaneh, "Protectiveeffectsofbioactivephytochemicalsfrom

Menthapiperita with multiplehealthpotentials.," Pharmacogn.Mag., vol. 6, pp. 147-153, 2010.

16. A. Nwinyi, O.C., Chinedu, N.S., Ajani, O.O., Ikpo, C., Ogunniran and O., "Antibacterialeffectsofextractsof Ocimumgratissimum and Piper guineense on Escherichiacoli and Staphylococcusaureus.," fr.J.FoodSci., vol. 3, pp. 2225, 2009.

17. X. Xu,S.,Yan,F.,Ni,Z.,Chen,Q.,Zhang,H.,andZheng, “Invitro and invivo controlof Alternariaalternata incherrytomatobyessentialoil from Laurusnobilis ofChineseorigin.," J.Sci.FoodAgric., vol. 94, pp. 1403-1408, 2014.

18. B. B. rasad,S.,Gupta,S.C.,andAggarwal, "Micronutrients andcancer:add spicetoyourlife," Nutr.DietCancer, pp. 23-48.

19. A. Elzwayie, H. A. Afan, M. F. Allawi, and A. El-Shafie, "'Heavy metal monitoring, analysis and prediction in lakes and rivers: state of the art," Environ. Sci. Pollut. Res., vol. 24, no. 13, pp. 12104-12117, 2017.

20. N. Shaheen et al., "Health risk assessment of trace elements via dietary intake of 'non-piscine protein source' foodstuffs (meat, milk and egg) in Bangladesh," Environ. Sci. Pollut.
Res., vol. 23, no. 8, pp. 7794-7806, 2016, doi: 10.1007/s11356-015-6013-2.

21. H. R. H. Takruri and A. F. M. Dameh, "Study of the Nutritional Value of Black Cumin Seeds (Nigella sativa L)," J. Sci. Food Agric., vol. 76, no. 3, pp. 404-410, 1998.

22. G. Regassa and B. S. Chandravanshi, "Levels of heavy metals in the raw and processed Ethiopian tobacco leaves," Springerplus, vol. 5, no. 1, p. 323, 2016.

23. and T.-S. X. L.-M. Cai, Z.-C. Xu, J.-Y. Qi, Z.-Z. Feng, "Assessment of exposure to heavy metals and health risks among residents near Tonglushan mine in Hubei, China," Chemosphere, vol. 127, pp. 127-135, 2015.

24. H. Ali, E. Khan, and I. Ilahi, "Environmental chemistry and ecotoxicology of hazardous heavy metals: Environmental persistence, toxicity, and bioaccumulation," J. Chem., vol. 2019, no. Cd, 2019, doi: 10.1155/2019/6730305.

25. Y. X. Tong R, Fang Y, Zhang B, Wang Y, "Monitoring and evaluating the control effect of dust suppressant on heavy metals based on ecological and health risks: a case study of Beijing," Env. Sci Pollut Res, vol. 28, pp. 14750-14763, 2020.

26. K. H. Sheijany MSP, ShariatiF MNY, "Evaluation of heavy metal contamination and ecological risk of soil adjacent to Saravan municipal solid waste disposal site, Rasht, Iran," Env. Monit Assess, vol. 192, p. 757, 2020.

27. H. M. Khan R, Islam MS, Tareq ARM, Naher K, Islam ARMT, M. Siddique MAB, Islam MA, Das S, Rashid MB, Ullah AKMA, and B. MMH, Masrura SU, Bodrud-Doza M, Sarker MR, "Elemental and polycyclic aromatic hydrocarbons distributions in the sediments of an urban river: influence of anthropogenic runoffs," Env. Nanotech Monit Manag, vol. 14:100318, 2020.

28. A. N. Panche, A. D. Diwan, and S. R. Chandra, "Flavonoids: An overview," J. Nutr. Sci., vol. 5, pp. 1-15, 2016, doi: 10.1017/jns.2016.41.

29. M. H. Kabir et al., "Potentially toxic elements in street dust from an urban city of a developing country: ecological and probabilistic health risks assessment," Environ. Sci. Pollut. Res., no. June, 2021, doi: 10.1007/s11356-021-14581-3.

30. M. E. Tyagi,A.K., Gottardi,D.,Malik,A., andGuerzoni, "Antiyeastactivityofmenthaoilandvapoursthrough invitro and invivo real fruitjuicesassays.," Food Chem., vol. 137, pp. 108-114, 2013.

31. Qadeera A, Saqib ZA, Ajmal Z, Xing C, Khalil SK, Usman M, Huang $Y$ and L. M. Bashir S, Ahmad Z, Ahmed J, Thebo KH, "Concentrations, pollution indices and health risk assessment of heavy metals in road dust from two urbanized cities of Pakistan: Comparing two sampling methods for heavy metals concentration," Sustain Cities Soc, vol. 53: 101959, 2020.

32. E. DeOliveira, T.L.C., dasGraçasCardoso, M., deAraújoSoares, R., Ramos and V. M. . M., Piccoli, R.H., andTebaldi, "Inhibitoryactivity of Syzygium aromaticum and Cymbopogoncitratus (DC.)Stapf.essentialoilsagainst Listeria monocytogenes inoculatedinbovinegroundmeat.," raz.J.Microbiol., vol. 44, pp. 357-365, 2013.

33. F. F. de Araújo, D. de Paulo Farias, I. A. Neri-Numa, and G. M. Pastore, "Polyphenols and their applications: An approach in food chemistry and innovation potential," Food Chem., vol. 338, no. July 2020, p. 127535, 2021, doi: 10.1016/j.foodchem.2020.127535.

34. P. Karak, "Biological Activities of Flavonoids: an Overview," Int. J. Pharm. Sci. Res., vol. 10, no. 4, p. 1567, 2019, doi: 10.13040/IJPSR.0975-8232.10(4).1567-74.

35. M. T. Shi, J., Wang, Y., Wei, H., Hu, J., \& Gao, . "Structure analysis of condensed tannin from rice straw and its inhibitory effect on Staphylococcus aureus," Crop. Prod., vol. 145, Artic, 2020.

36. et al. Boukid, F., Dall'Asta, M., Bresciani, L., Mena, P., Del Rio, D., Calani, L., "henolic profile and antioxidant capacity 
of landraces, old and modern Tunisian durum wheat," Eur. Food Res. Technol., vol. 245, pp. 73-82, 2019.

37. A. Peerakam, N., Wattanathorn, J., Suchart, P., Buamongkol, S., Sirisa-ard, P. and S. . Chansakaow, "Chemicalprofilingofessentialoilcompositionand biologicalevaluationof

Anethumgraveolens L.(Seed)growninThailand.," J.Nat. Sci. Res., vol. 4, pp. 3441, 2014.

38. Mocciaro, G., Bresciani, L., Tsiountsioura, M., Martini, D., Mena, P., Charron, M., ... Ray and S, "Dietary absorption profile, bioavailability of (poly)phenolic compounds, and acute modulation of vascular/endothelial function by hazelnut skin drink," J. Funct. Foods, vol. 63, 2019.

39. \& Iglesias-Carres, L., Mas-Capdevila, A., Bravo, F. I., Aragonès, G., Arola-Arnal, A. and B. Muguerza, . "A comparative study on the bioavailability of phenolic compounds from organic and nonorganic red grapes," Food Chem., vol. 299, 2019.

40. L. Woguem, V., Maggi, F., Fogang, H.P., Tapondjoua, L.A., Womeni, $\mathrm{H}$. M. and $\mathrm{E}$. "Antioxidant, antiproliferativeandantimicrobialactivitiesof thevolatileoilfromthewildpepper

Pipercapense
usedinCameroonasa culinaryspice.," Nat.Prod.Comm, vol. 8, pp. 1791-1769, 2013.

41. G. Zheleva-Dimitrova, D., Simeonova, R., Gevrenova, R., Savov, Y., Balabanova, V., NasarEddin, "). In vivo toxicity assessment of Clinopodium vulgare $\mathrm{L}$. water extract characterized by UHPLC-HRMS," . Food Chem. Toxicol., vol. 134, Artic, 2019.

42. D. Pina-Pérez,M.C.,Martínez-López,A.,andRodrigo, "Cinnamon antimicrobialeffectagainst Salmonella Typhimuriumcellstreatedbypulsed electricfields(PEF)inpasteurizedskimmilkbeverage.,"

FoodRes.Int., vol. 48, pp. 777-783, 2012.

43. et al. Chen, S., Wu, F., Li, Y., Qian, Y., Pan, X., Li, F., "NtMYB4 and NtCHS1 Are critical factors in the regulation of flavonoid biosynthesis and are involved in salinity responsiveness," Front. Plant Sci., vol. 178, 2019.

44. A. Shirshova, T., Beshlei, I., Deryagina, V., Ryzhova, N., "Chemicalcompositionof leavesandinhibitoryeffectof theirextractontumorgrowthinmice," Pharm.Chem.J., vol. 46, no. 11, pp. 672-675, 2013. 